DOI: https://doi.org/10.12797/Politeja.15.2018.54.17

Agnieszka NITSZKE

Uniwersytet Jagielloński

agnieszka.nitszke@uj.edu.pl

\title{
EUROPEJSKA SŁUŻBA DZIAŁAŃ ZEWNĘTRZNYCH - NOWA JAKOŚĆ DYPLOMACJI UNIJNEJ?
}

\section{ABSTRACT European External Action Service - a new quality of EU diplomacy?}

The European External Action Service (EEAS) was established based on the Treaty of Lisbon. The objective of the creation of the EEAS was to increase the role of the European Union in the international arena and increase the effectiveness of the Union's external actions. The aim of the article is to discuss the international position of the Union and its international roles, and then to present the legal foundations of the EEAS. The next part analyzes changes in the functioning of the EEAS undertaken by both high representatives - Catherine Ashton and Federica Mogherini. In conclusion, an attempt was made to answer the question of whether the European Union needs autonomous diplomacy and whether the EEAS can be treated as EU diplomacy.

Key words: European External Action Service, European Union, diplomacy

Słowa kluczowe: Europejska Służba Działań Zewnętrznych, Unia Europejska, dyplomacja 


\section{UWAGI WSTEPNE ${ }^{1}$}

Unia Europejska jako organizacja międzynarodowa pełni szereg funkcji i odgrywa wiele ról, w tym międzynarodowych. I choć główny obszar jej działalności dotyczy spraw i polityk wewnętrznych, to relacje zewnętrzne nabierają coraz większego znaczenia. Oprócz tradycyjnych kontaktów handlowych i gospodarczych rozwijanych z państwami trzecimi właściwie od powstania Wspólnot w latach 50. XX w. Unia stara się umocnić swoją pozycję polityczną, a do tego bez wątpienia potrzebna jest skuteczna dyplomacja. Stownik jezyka polskiego PWN definiuje dyplomację jako: dziatalnośćprzedstawicieli danego państwa reprezentujacych jego interesy za granica; ale też jako: instytucje, urzędy oraz ich pracowników zajmujacych się taka dziatalnościa oraz umiejętność zachowania się w trudnej sytuacji tak, aby nikogo nie urazić i osiagnać zamierzony cel ${ }^{2}$. Unia Europejska jako zbiorowy podmiot stosunków międzynarodowych nie zastępuje państw członkowskich w ich kompetencjach na arenie międzynarodowej, lecz powinna je wspomagać, tak by osiągnąć efekt synergii i wzmocnić interes całej wspólnoty w relacjach z innymi państwami czy organizacjami międzynarodowymi. Celem niniejszego artykułu jest próba znalezienia odpowiedzi na następujące pytania badawcze: Czy Unia Europejska potrzebuje dyplomacji?, Czy dyplomacja Unii Europejskiej posiada takie same cechy jak dyplomacja państw?, Czy ustanowienie Europejskiej Służby Działań Zewnętrznych (ESDZ) przyczyniło się do zwiększenia pozycji międzynarodowej Unii Europejskiej?

ESDZ jest strukturą stosunkowo nową w ramach systemu instytucjonalnego Unii Europejskiej, niemniej jednak przeszło siedmioletni okres jej działalności pozwala formułować wnioski na temat jej funkcjonowania. W polskiej literaturze przedmiotu temat działań zewnętrznych UE jest stosunkowo często podejmowany, jednak brak jest kompleksowych opracowań poświęconych bezpośrednio funkcjonowaniu ESDZ. W polskich badaniach można odnotować artykuł Krzysztofa Szczerskiego Gtuchy telefon. Oproblemach Unii Europejskiej jako aktora polityki międzynarodowej (2012)3. Z kolei w literaturze anglojęzycznej warto zwrócić uwagę na kilka pozycji, które ukazały się w przeciągu ostatnich trzech lat i zawierają analizę pierwszego okresu funkcjonowania ESDZ, w tym monografię Mauro Gattiego European External Action Service. Promoting Coherence through Autonomy and Coordination (2016) ${ }^{4}$, a także The European External Action Service. European Diplomacy Post-Westphalia, pod redakcją Davida

Artykuł został napisany w ramach grantu Jean Monnet Chair EUCRIS: European Union in Crisis: What is Wrong and How to Fix It? (nr 575240-EPP-1-2016-1-PL-EPPJMO_CHAIR).

2 dyplomacja, [w:] Stownikjezzykapolskiego PWN, [online] https://sjp.pwn.pl/sjp/dyplomacja;2555680. html, 30 III 2018.

3 K. Szczerski, Gtuchy telefon. O problemach Unii Europejskiej jako aktora polityki międzynarodowej, [w:] Amerykomania. Ksiega jubileuszowa prof. dr. hab. Andrzeja Mani, t. 2, red. W. Bernacki, A. Walaszek, Kraków 2012, s. 803-818.

4 M. Gatti, European External Action Service. Promoting Coherence through Autonomy and Coordination, Leiden 2016. 
Spence'a i Jozefa Bátory $(2015)^{5}$, The European External Action Service and National Foreign Ministries. Convergence or Divergence?, pod redakcją Rosy Balfour, Cateriny Carty i Kristi Raik (2015) , czy najnowszą pozycję dotyczącą tej tematyki autorstwa Josta-Henrika Morgenstern-Pomorskiego The Contested Diplomacy of the European External Action Service. Inception, Establishment and Consolidation (2018).

Artykuł został oparty na badaniach jakościowych, przede wszystkim metodzie analizy zawartości oraz metodzie komparatystycznej. Przeanalizowane zostały głównie dokumenty, w tym traktat lizboński, Decyzja Rady z dnia 26 lipca 2010 r. określajacca organizacje $i$ zasady funkcjonowania Europejskiej Stużby Dziatań Zewnętrznych (Dz.U. UE L, 2010, nr 201) oraz propozycje zmian w strukturze i funkcjonowaniu Służby. Następnie w oparciu o wytyczne tam zawarte dokonano porównania stanu prawnego z faktycznym i podjęto próbę odpowiedzi na wcześniej sformułowane pytania badawcze.

Artykuł składa się z trzech części. W pierwszej zawarte są ogólne rozważania na temat pozycji międzynarodowej Unii Europejskiej i jej ról międzynarodowych. Kwestia ta jest kluczowa dla odpowiedzi na pytanie, czy Unii potrzebna jest dyplomacja, a jeśli tak, to jaka. W kolejnych dwóch częściach opracowania znajduje się omówienie podstaw prawnych ESDZ oraz zmian w jej funkcjonowaniu. Całość zamyka podsumowanie, w którym znajdują się odpowiedzi na pytania badawcze o sens i charakter ESDZ.

\section{MIĘDZYNARODOWE ROLE UNII EUROPEJSKIEJ}

Unia Europejska buduje swoją pozycję międzynarodową przede wszystkim w oparciu o relacje handlowe i zależności gospodarcze, ale nie bez znaczenia są również wartości, które leżą u podstaw całej współpracy europejskiej. Tożsamość międzynarodowa UE przez długi czas wynikała przede wszystkim z definicji jej samej jako szczególnego rodzaju wspólnoty interesów i wartości łączących państwa należące do tego samego kręgu cywilizacyjnego. Ta autodefinicja poważnie ograniczała możliwości realnego oddziaływania Unii w stosunkach międzynarodowych, ponieważ nie zawierała jednoznacznego wskazania, która instytucja lub - szerzej - podmiot w Unii jest odpowiedzialny za prowadzenie polityki międzynarodowej. Po wejściu w życie traktatu lizbońskiego pozycja Unii Europejskiej w stosunkach międzynarodowych się wzmocniła ${ }^{8}$, szczególnie przez wyposażenie jej w osobowość prawnomiędzynarodową, której wcześniej nie

The European External Action Service. European Diplomacy Post-Westphalia, red. D. Spence, J. Bátora, Basingstoke 2015.

6 The European External Action Service and National Foreign Ministries. Convergence or Divergence?, red. R. Balfour, C. Carta, K. Raik, New York 2015.

7 J.-H. Morgenstern-Pomorski, The Contested Diplomacy of the European External Action Service. Inception, Establishment and Consolidation, New York 2018.

8 Szerzej na temat zmian w obszarze wspólnej polityki zagranicznej i bezpieczeństwa wprowadzonych traktatem lizbońskim zob.: J.J. Węc, Traktat lizboński. Polityczne aspekty reformy ustrojowej Unii Europejskiej w latach 2007-2009, Kraków 2011, s. 247-267. 
posiadała, a jedynie korzystała z podmiotowości Wspólnot. Postępująca instytucjonalizacja w zakresie polityki zagranicznej UE ma swoje konsekwencje, jak ujmuje to Karen Smith: Deklaracje i oświadczenia powoduja, że od Unii oczekuje sie podejmowania dziatań. Utrudnia to jednocześnie wycofywanie sie ze ztożonych obietnic realizacji okreslonych zadań. Dzięki temu tożsamość międzynarodowa UE powoli i stopniowo zyskuje naznaczeniu?.

Tożsamość międzynarodowa UE wynika z ról międzynarodowych, które ta organizacja odgrywa, bądź pretenduje do ich odgrywania, na arenie międzynarodowej. Najprostsza typologia opiera się na kryterium zasięgu geograficznego wpływów. W tym ujęciu UE odgrywa, po pierwsze: rolę mocarstwa regionalnego, po drugie: podmiotu mogącego wpływać na bezpieczeństwo międzynarodowe w szerszym ujęciu, a zatem także na sytuację na innych kontynentach, lecz z pewnymi ograniczeniami, i po trzecie: podmiotu mającego zdolność globalnego oddziaływania ${ }^{10}$. Ryszard Zięba proponuje ujęcie funkcjonalne ról międzynarodowych UE, grupując je w trzy podstawowe kategorie: role ekonomiczne, role polityczne i na końcu rolę kulturowo-cywilizacyjną ${ }^{11}$. Role ekonomiczne także można podzielić na dwie kolejne kategorie. Pierwsza z nich obejmuje rolę lidera zrównoważonego rozwoju i wzorzec udanej integracji oraz rolę lidera handlu światowego. Jednak dużo większe znaczenie, z punktu widzenia kreowania wizerunku międzynarodowego, mają role związane z zaangażowaniem Unii w udzielanie pomocy rozwojowej i humanitarnej. Role polityczne sprowadzają się zasadniczo do aktywności dyplomatycznej, przede wszystkim na forach innych organizacji międzynarodowych, a także zaangażowania w pokojowe rozwiązywanie konfliktów w różnych częściach świata. Rola kulturowo-cywilizacyjna często bywa pomijana w rozmaitych typologiach, lecz biorąc pod uwagę to, że Unia stanowi wspólnotę wartości, nie można tego elementu lekceważyć, tym bardziej że kultura europejska oraz tradycyjne wartości polityczne, na których straży stoi Unia, są magnesem przyciągającym co roku do Europy nie tylko dziesiątki tysięcy imigrantów z różnych części świata, ale także inwestorów czy w końcu rządy innych państw, oczekujących wsparcia w demokratyzowaniu ich ustrojów czy przemianach gospodarczych ${ }^{12}$.

W skali regionu, czyli Europy, UE osiągnęła pełny sukces - jej pozycji mocarstwa regionalnego nikt nie kwestionuje, bo też Unia po rozszerzeniach, które miały miejsce w XXI w., obejmuje już niemal cały kontynent. Z kolei w skali globalnej mocarstwowość Unii, z wyjątkiem gospodarki, jest bardziej deklaratywna aniżeli faktyczna i szans na szybką zmianę pozycji w tym aspekcie obecnie nie ma, choć podejmowane są działania, by ten stan przezwyciężyć, a jednym z instrumentów temu służących może być ESDZ.

K. Smith, European Union Foreign Policy in a Changing World, Cambridge 2003, s. 197-198.

10 Taką typologię ról międzynarodowych UE proponuje m.in. Roman Kuźniar. Zob. tenże, Tożsamość międzynarodowa Europy (UE), [w:] Unia Europejska. Nowy typ wspólnoty międzynarodowej, red. E. Haliżak, S. Parzymies, Warszawa 2002, s. 25-44.

11 R. Zięba, Unia Europejska jako aktor stosunków międzynarodowych, Warszawa 2003, s. 244-266.

12 Tamże. 


\section{PODSTAWY PRAWNE EUROPEJSKIEJ SŁUŻBY DZIAŁAŃ ZEWNĘTRZNYCH}

Traktat lizboński miał przyczynić się nie tylko do uporządkowania systemu instytucjonalnego, ale także do wzmocnienia Unii w wymiarze wewnętrznym i zewnętrznym. Jednym z elementów reformy lizbońskiej było ustanowienie nowej struktury w postaci Europejskiej Służby Działań Zewnętrznych, która miała za zadanie przyczynić się do większej spójności w zakresie polityk zewnętrznych UE. Bezpośrednią podstawą traktatową utworzenia ESDZ jest art. 27 ust. 3 Traktatu o Unii Europejskiej (TUE), który stanowi, że: $W$ wykonywaniu swojego mandatu wysoki przedstawiciel jest wspomagany przez Europejską Stużbę Dziatań Zewnętrznych. Stużba ta wspótpracuje ze stużbami dyplomatycznymi Państw Cztonkowskich i sktada się z urzędników wtaściwych stużb Sekretariatu Generalnego Rady i Komisji, jak również z personelu delegowanego przez krajowe stużby dyplomatyczne. Organizację izasady funkcjonowania Europejskiej Stużby Dziatań Zewnętrznych określa decyzja Rady. Rada stanowi na wniosek wysokiego przedstawiciela po konsultacji z Parlamentem Europejskim i po uzyskaniu zgody Komisji.

Jak piszą Maxime Lefebvre i Christophe Hillion w analizie dotyczącej ustanowienia ESDZ, traktat lizboński tworzył możliwości dalszego realnego rozwoju dyplomacji unijnej, jednak nie przesądzał w konkretny sposób, jak sama ESDZ ma być skomponowana ani jak ma funkcjonować w szczegółach ${ }^{13}$. Te kwestie miała regulować wspomniana decyzja Rady.

Należy także zwrócić uwagę na dwie deklaracje - 13 i 14 - w sprawie wspólnej polityki zagranicznej i bezpieczeństwa dołączone do traktatu lizbońskiego. Precyzują one, że utworzenia urzędu wysokiego przedstawiciela Unii do spraw zagranicznych i polityki bezpieczeństwa (dalej: wysoki przedstawiciel) oraz Europejskiej Służby Działań Zewnętrznych, po pierwsze, nie naruszają obecnej odpowiedzialności Państw Cztonkowskich za ksztattowanie i prowadzenie wtasnej polityki zagranicznej ani sposobu, w jaki sq one reprezentowane w państwach trzecich i organizacjach międzynarodowych (Deklaracja nr 13) $)^{14}$ oraz, po drugie, nie będa miaty wptywu na obowiazujacca podstawe prawna, odpowiedzialność ani uprawnienia każdego Państwa Cztonkowskiego w zakresie ksztaltowania i prowadzenia wtasnej polityki zagranicznej, krajowej stużby dyplomatycznej, stosunków z państwami trzecimi oraz uczestnictwa $w$ organizacjach międzynarodowych, $w$ tym na cztonkostwo Państwa Cztonkowskiego w Radzie Bezpieczeństwa ONZ (Deklaracja nr 14) ${ }^{15}$. W ten sposób nałożono ograniczenia podmiotowe i przedmiotowe na działalność nowej struktury.

13 M. Lefebvre, C. Hillion, The European External Action Service: Towards a Common Diplomacy?, Swedish Institute for European Policy Studies, European Policy Analysis 2010:6, s. 1, [online] http:// www.asser.nl/upload/documents/712010_949533-SIEPS\%20-\%20EEAS\%20-\%202010_6epa.pdf, 20 II 2018.

14 13. Deklaracja w sprawie wspólnej polityki zagranicznej i bezpieczeństwa. Wersje skonsolidowane Traktatu o Unii Europejskiej i Traktatu of funkcjonowaniu Unii Europejskiej, Dz.U. UE C, 2016, nr 202, s. 343.

15 14. Deklaracja w sprawie wspólnej polityki zagranicznej i bezpieczeństwa. Wersje skonsolidowane traktatu..., s. 343. 
Inne przepisy traktatu lizbońskiego pośrednio odnoszące się do reprezentacji UE na zewnątrz znajdują się w art. 221 Traktatu o funkcjonowaniu Unii Europejskiej (TFUE), który dotyczy delegatur UE w państwach trzecich i przy organizacjach międzynarodowych. Za ich funkcjonowanie i koordynowanie ich działalności odpowiada wysoki przedstawiciel. Decyzja określająca organizację i zasady funkcjonowania ESDZ została przyjęta przez Radę 26 lipca 2010 r. ${ }^{16}$ Precyzuje ona charakter i zakres działań ESDZ oraz jej zadania. Decyzja gwarantuje autonomię i zapewnia zdolność prawną ESDZ w celu wykonywania przyznanych jej zadań, do których należą w ujęciu podmiotowym wspieranie wysokiego przedstawiciela, a także przewodniczących Rady do Spraw Zagranicznych i Rady Europejskiej oraz Komisji Europejskiej i jej przewodniczącego; natomiast w ujęciu przedmiotowym ESDZ ma opracowywać na zlecenie wysokiego przedstawiciela założenia w zakresie wspólnej polityki zagranicznej i bezpieczeństwa oraz wspólnej polityki bezpieczeństwa i obrony, a także realizować je i czuwać nad spójnością działań zewnętrznych UE.

Decyzja dookreśliła również relacje między ESDZ a służbami dyplomatycznymi państw członkowskich oraz z Sekretariatem Generalnym Rady i służbami Komisji, zobowiązując wszystkie wskazane podmioty do współpracy. Dodatkowo ESDZ ma udzielać wsparcia w zakresie swoich zadań innym instytucjom i organom UE, w szczególności Parlamentowi Europejskiemu oraz agencjom unijnym, a z drugiej strony sama może korzystać z ich usług i nawiązywać z nimi współpracę.

Decyzja Rady z 2010 r., w nawiązaniu do art. 27 ust. 3 TUE, dookreśliła strukturę wewnętrzną Służby. Sama ESDZ podlega wysokiemu przedstawicielowi, jednak za jej funkcjonowanie, także w sensie administracyjnym oraz koordynowania działań podejmowanych przez jednostki Służby, w tym delegatury, odpowiada wykonawczy sekretarz generalny, którego - zgodnie z decyzją - wspiera dwóch zastępców ${ }^{17}$. Administracja centralna Służby znajduje się w Brukseli i jest podzielona na dyrekcje, których aktualnie jest osiem; sześć dyrekcji zarządzających (ang. Managing Directorate - MD)

16 Decyzja Rady z dnia 26 lipca 2010 r. określająca organizację i zasady funkcjonowania Europejskiej Stużby Dziatań Zewnętrznych, Dz.U. UE L, 2010, nr 201.

17 Tak stanowi art. 4 ust. 2 Decyzji Rady z dnia 26 lipca 2010 r...., s. 33. Jednak od 2015 r. jest trzech zastępców sekretarza generalnego: zastępca ds. gospodarczych i problemów globalnych, zastępca ds. politycznych (dyrektor polityczny) oraz zastępca ds. wspólnej polityki bezpieczeństwa i obrony oraz reagowania kryzysowego. Zmiany te zostały wprowadzone decyzją wysokiego przedstawiciela w lipcu 2015 r. i zaczęły obowiązywać od 16 września tego samego roku. Report of the High Representative of the Union for Foreign Affairs and Security Policy of 22 December 2015 to the Council on implementing the EEAS Review, Brussels, 11 I 2016 (OR. en), [online] http://data.consilium.europa.eu/doc/document/ST-5113-2016-INIT/en/pdf, 20 III 2018; zob. także: European External Action Service, $H Q$ Organisation Chart as of $16^{\text {th }}$ March 2018, [online] https://eeas.europa.eu/sites/eeas/files/2018-16-03_-_eeas_2.0_orgchart_0.pdf, 30 III 2018. Zmiany w strukturze organizacyjnej ESDZ były podyktowane ogólną polityką Unii związaną z poszukiwaniem oszczędności, w ramach której zobligowano wszystkie jednostki unijne do redukcji zatrudnienia o 1\% w skali roku w latach 2013-2017. Odnośnie do ESDZ podjęto decyzję, że redukcja etatów odbędzie się na poziomie centrali, a nie w delegaturach. W 2016 r. zredukowano liczbę pracowników o 17 osób. Zob.: European External Action Service, Annual Activity Report for 2016, 8 VI 2017, s. 9-10, [online] https://eeas.europa.eu/sites/eeas/files/ aar2016_final_final.pdf, 20 III 2018. 
odpowiedzialnych głównie za poszczególne regiony świata: MD Afryka, MD Ameryki, MD ASIAPAC (Azja i Pacyfik), MD EURCA (Europa i Azja Środkowa), MD MENA (Bliski Wschód i Afryka Północna) oraz MD GLOBAL zajmująca się prawami człowieka oraz problemami globalnymi i stosunkami wielostronnymi ${ }^{18}$. Strukturę uzupełniają dwie dyrekcje generalne (ang. Directorate General - DG): DG-BA - ds. budżetu i administracji oraz Sztab Wojskowy Unii Europejskiej (ang. European Union Military Staff - EUMS), podlegający bezpośrednio wysokiemu przedstawicielowi. W ramy organizacyjne ESDZ włączono także inne organy wspólnej polityki bezpieczeństwa i obrony ${ }^{19}$.

Jednak największe znaczenie z punktu widzenia rozwoju dyplomacji unijnej ma określenie w decyzji Rady statusu i zadań delegatur Unii. Kwestię tę reguluje art. 5 omawianej decyzji. Stanowi on, że decyzję w sprawie otwarcia lub zamknięcia delegatury przyjmuje wysoki przedstawiciel w porozumieniu z Radą i Komisją. Na czele każdej delegatury stoi jej szef, któremu podlega cały zatrudniony w niej personel. Szef delegatury jest bezpośrednio odpowiedzialny przed wysokim przedstawicielem, od którego otrzymuje instrukcje i przed którym odpowiada za ich realizację. W określonych przypadkach instrukcje takie może szefowi delegatury wydawać również Komisja, mogą to być np. środki operacyjne związane z realizacją projektów unijnych w państwie trzecim (art. 5 ust. 3 i 4). Każda delegatura Unii podlega okresowej kontroli finansowej i administracyjnej, którą przeprowadza wykonawczy sekretarz generalny ESDZ ${ }^{20}$.

Bardzo istotnym elementem wskazującym na próbę upodobnienia statusu delegatur unijnych do przedstawicielstw dyplomatycznych państw jest rozciągnięcie na nie ochrony $\mathrm{w}$ postaci zapewnienia przez państwa przyjmujące personelowi delegatur przywilejów i immunitetów dyplomatycznych zgodnie z postanowieniami konwencji wiedeńskiej o stosunkach dyplomatycznych z 18 kwietnia $1961 \mathrm{r}$. Ma to na celu zapewnienie nie tylko bezpieczeństwa, ale przede wszystkim pełnej swobody działalności dyplomatycznej delegatur.

Zadania delegatur określają ust. 7-10 art. 5 decyzji Rady. Po pierwsze, delegatury mają ułatwiać kontakty instytucji Unii Europejskiej z państwami trzecimi lub organizacjami międzynarodowymi, przy których są akredytowane. Po drugie, szef delegatury reprezentuje Unię jako całość w państwie trzecim lub przed organizacją międzynarodową, przy której jest akredytowany, w tym ma uprawnienia do zawierania umów i występowania przed sądami jako strona $\mathrm{w}$ postępowaniu. Po trzecie, delegatury są zobowiązane do utrzymywania regularnych kontaktów z misjami dyplomatycznymi państw członkowskich UE i wymiany informacji. Po czwarte, na wniosek państw członkowskich delegatury wspierają państwa członkowskie w ich zadaniach, w tym w zakresie opieki konsularnej nad obywatelami UE.

18 European External Action Service, HQ Organisation Chart...

19 Tamże. Por. J.J. Węc, Proces implementacji traktatu lizbońskiego w latach 2009-2013, „Politeja” 2015, nr 35, s. 343, [online] http://dx.doi.org/10.12797/Politeja.12.2015.35.24.

20 Art. 5 ust. 5 stanowi, że delegatury Unii podlegają także kontroli Europejskiego Urzędu ds. Zwalczania Nadużyć Finansowych (fr. L’Office européen de lutte antifraude - OLAF). 
W zakresie wymogów i obowiązków stawianych przed personelem ESDZ należy wskazać na uniezależnienie pracowników od możliwości wywierania na nich wpływów przez państwa członkowskie. Mają oni bowiem kierować się wyłącznie interesem UE (art. 6 ust. 4). Tą decyzją Rada stara się także zwiększyć demokratyczny charakter nowej struktury i zapewnić jej większą akceptowalność w państwach członkowskich poprzez zapewnienie odpowiedniej równowagi geograficznej w procesie rekrutacji personelu (art. 6 ust. 6).

W zakresie koordynacji działań zewnętrznych Unii ESDZ jest limitowana kompetencjami Komisji Europejskiej. Nie jest to jednak negatywne ograniczenie, lecz mające swoje uzasadnienie w pozycji KE, która jest odpowiedzialna za wykonanie budżetu UE oraz realizację polityk unijnych. Analizowana decyzja Rady podkreśla związki funkcjonalne między KE a ESDZ oraz wprowadza instrumenty współpracy między nimi. ESDZ jest odpowiedzialna za opracowywanie na potrzeby Komisji krajowych i regionalnych dokumentów strategicznych oraz programów orientacyjnych, które pozwalają Komisji formułować odpowiednią politykę w odniesieniu do poszczególnych państw trzecich czy całych regionów, także w zakresie przydziału środków finansowych. Ważne jest również uwzględnienie roli ESDZ w zakresie programowania Europejskiej Polityki Sąsiedztwa, która ma strategiczne znaczenie z punktu widzenia bezpieczeństwa UE (art. 9 ust. 5), a także współpraca w koordynowaniu działalności instrumentów pomocy zewnętrznej (art. 9 ust. 1-2).

Decyzja Rady obligowała wysokiego przedstawiciela do dokonania przeglądu organizacji i funkcjonowania ESDZ do połowy 2013 r., a następnie przedstawienia stosownych wniosków Radzie (art. 13 ust. 3).

\section{OCENA FUNKCJONOWANIA}

Catherine Ashton, wysoka przedstawiciel w latach 2009-2014, przedstawiła raport z przeglądu ESDZ, zgodnie z planem, w lipcu 2013 r. W dokumencie podkreślono, że ESDZ jest nowym i wyjątkowym tworem, który harmonizuje wszystkie strategie polityczne i środki będące we wspólnym posiadaniu UE oraz umożliwia ich skoncentrowanie na budowaniu wptywu i osiaganiu wyników na catym świecie $w$ celu promowania wartości i interesów $U E^{21}$. Zaznaczono jednocześnie, że Służba nie stanowi konkurencji dla ministerstw spraw zagranicznych państw członkowskich i nie ma ambicji przekształcenia się w ministerstwo spraw zagranicznych Unii, lecz jest zupełnie nowym podmiotem, którego celem jest budowanie silnej pozycji międzynarodowej UE w oparciu o połączone potencjały państw członkowskich i struktur unijnych. Przedstawiono także mocne strony ESDZ po dwóch i pół roku jej funkcjonowania oraz rekomendacje zmian, które powinny być wprowadzone, by zwiększyć efektywność działań Służby.

21 European External Action Service, Przeglad ESDZ 2013, s. 3, [online] http://collections.internetmemory.org/haeu/20160313172652/http://eeas.europa.eu/library/publications/2013/3/2013 eeas_review_pl.pdf, 20 III 2018. 
Jako osiągnięcia pierwszego okresu działalności ESDZ uznano: po pierwsze, ustanowienie struktury organizacyjnej i ustalenie priorytetów działania, które pozwoliły na zaangażowanie się ESDZ w zakresie wszystkich kwestii geograficznych (regiony świata) i tematycznych, a także zbudowanie sieci delegatur Unii, która w 2013 r. obejmowała 139 jednostek zapewniających reprezentację w 163 państwach i organizacjach międzynarodowych; po drugie, zdolność realnego oddziaływania na państwa sąsiedzkie; po trzecie, dobrą współpracę ze służbami dyplomatycznymi państw członkowskich, co umożliwia bardziej efektywne działania oraz podział pracy ${ }^{22}$.

Propozycje zmian zawarte w Przeglądzie podzielono na krótko- i średnioterminowe. Pierwsza kategoria obejmowała 26 punktów podzielonych na 3 obszary: organizacja, funkcjonowanie i personel. Zdecydowana większość zawartych tam postulatów dotyczyła drobnych korekt w dotychczasowym systemie, choć warto zwrócić uwagę na pkt 20, który wskazywał na dość istotny problem, a mianowicie powielanie zadań przypisanych jednocześnie ESDZ, Komisji i Radzie, co zdecydowanie zmniejsza efektywność pracy ${ }^{23}$. Druga kategoria była podzielona na dwa obszary: organizację oraz funkcjonowanie i obejmowała dziewięć punktów, z których dwa miały szczególne znaczenie. Punkt 4 zawierał postulat wzmocnienia pozycji wysokiego przedstawiciela, a jednocześnie wiceprzewodniczącego Komisji w kierunku możliwości większego oddziaływania na politykę Komisji w zakresie programów pomocy zewnętrznej. Z kolei pkt 5 dotyczył organizacji wewnętrznej Służby i rekomendował połączenie stanowiska wykonawczego sekretarza generalnego i dyrektora do spraw operacyjnych oraz ograniczenie liczby dyrektorów generalnych ${ }^{24}$.

Samoocena dokonana przez ESDZ ma oczywiście swoją wartość, ponieważ pozwala ocenić potencjalną wolę zmian. Niemniej jednak warto konfrontować tego typu dokumenty z niezależnymi analizami. Carnegie Europe, jeden z najbardziej cenionych think tanków europejskich ${ }^{25}$, przedstawił w listopadzie 2012 r., a zatem jeszcze przed oficjalnym Przeglądem, własne rekomendacje. Autor rekomendacji, Stefan Lehne, zaznaczył: nadzieja, że ESDZ będzie stużyć jako skuteczna platforma koordynacji zarówno klasycznej polityki zagranicznej i bezpieczeństwa, jak i zewnętrznych kompetencji Komisji, jak dotad nie zostata spetniona ${ }^{26}$. Dostrzeżono, że współpraca między ESDZ a służbami dyplomatycznymi państw członkowskich, które dysponują dużo większym potencjałem i doświadczeniem, nie jest w pełni wykorzystana.

\footnotetext{
Tamże.

23 Tamże, s. 17.

24 Tamże, s. 19.
}

25 Carnegie Europe jest filią działającego w Stanach Zjednoczonych think tanku Carnegie Endowment for International Peace. W prestiżowym rankingu think tanków Global Go To Think Tank 2016 Carnegie Europe zajął dziewiątą pozycję wśród think tanków zajmujących się tematyką europejską. J.G. McGann, 2016 Global Go To Think Tank Index Report, University of Pennsylvania Scholary Commons, 26 I 2017, s. 70, [online] https://repository.upenn.edu/cgi/viewcontent.cgi ?article=1011\&context=think_tanks, 20 III 2018.

26 S. Lehne, The Review of the European External Action Service in 2013, Carnegie Europe, 14 XI 2012, [online] http://carnegieeurope.eu/strategiceurope/50020, 20 III 2018. 
Jednym z najważniejszych punktów wskazanych w omawianej analizie jest propozycja przeniesienia kompetencji w zakresie kreowania i realizacji Europejskiej Polityki Sąsiedztwa w całości do ESDZ. Kolejny punkt dotyczy konieczności wzmocnienia potencjału ESDZ w zakresie kluczowych w dzisiejszym świecie polityk klimatycznej, energetycznej i migracyjnej, tak by działania Unii w tych obszarach były bardziej skoordynowane i aby Unia mogła skuteczniej promować rozwiązania w tych obszarach na arenie międzynarodowej, co wiąże się z kolejnym postulatem, a mianowicie większą koordynacją działań na forach międzynarodowych, gdzie przedstawiciele Unii powinni mieć możliwość zabierania głosu nie tylko w imieniu Unii, ale także wszystkich państw członkowskich ${ }^{27}$.

Dnia 17 grudnia 2013 r., podczas spotkania Rady do Spraw Ogólnych, przyjęto Przegląd ESDZ przedstawiony przez wysoką przedstawiciel w lipcu tego samego roku. W konkluzjach z posiedzenia Rady wskazano na ogrom pracy włożonej w zorganizowanie Służby oraz przyjęto do wiadomości rekomendacje zawarte w Przeglądzie. Wskazano jednocześnie, że należy dalej pracować nad poprawą funkcjonowania Służby. Zadanie to powierzono kolejnemu wysokiemu przedstawicielowi, który miał przygotować własne propozycje przed końcem 2015 r. (pkt 11 konkluzji) ${ }^{28}$.

Federica Mogherini, sprawująca urząd wysokiego przedstawiciela od 2014 r., przedstawiła 22 grudnia 2015 r. raport na temat postępów wdrażania Przeglądu ESDZ ${ }^{29}$. W raporcie wskazano, że nie ma potrzeby niezwłocznych działań ze strony Rady w celu zmiany Decyzji Rady z dnia 26 lipca 2010 r. określajacej organizację i zasady funkcjonowania Europejskiej Stużby Dziatań Zewnętrznych ani zmian w regulaminie pracowniczym regulującym zasady zatrudnienia w Służbie. Podkreślono, że część rekomendacji zawartych w Przeglądzie została już zrealizowana, w tym kwestie związane z racjonalizacją struktury organizacyjnej (w 2015 r.). Dodatkowo wzmocniono pozycję wysokiego przewodniczącego/wiceprzewodniczącego KE poprzez utworzenie w Komisji pod przewodnictwem Jeana-Claude’a Junckera Grupy Komisarzy ds. Działań Zewnętrznych (ang. Commissioners' Group on External Action), w której skład wchodzą komisarze ds.: Europejskiej Polityki Sąsiedztwa i negocjacji w sprawie rozszerzenia, współpracy międzynarodowej i rozwoju, pomocy humanitarnej i zarządzania kryzysowego oraz handlu. Grupie przewodniczy wysoka przedstawiciel, a jej spotkania odbywają się przynajmniej raz w miesiącu ${ }^{30}$, co w istotny sposób zwiększyło koordynację działań zewnętrznych na poziomie Komisji Europejskiej.

\section{Tamże.}

28 Council of the European Union, Council conclusions on the EEAS Review. General Affairs Council meeting, Brussels, 17 XII 2013, s. 3, [online] http://www.consilium.europa.eu/uedocs/cms_data/ docs/pressdata/EN/genaff/140141.pdf, 20 III 2018.

29 Report of the High Representative..., s. 1-9.

30 Decyzję o utworzeniu Grupy podjął przewodniczący Komisji Jean-Claude Juncker 11 XI 2014 r. S. Blockmans, S. Russack, The Commissioners' Group on External Action - Key Political Facilitator, CEPS Special Report, no. 125, XII 2015, s.8, [online] http://aei.pitt.edu/70407/1/SR125_SB_and_ SR_Commissioners_Group_on_External_Action.pdf, 20 III 2018. 


\section{PODSUMOWANIE}

Jednym z celów ustanowienia ESDZ była chęć zwiększenia roli międzynarodowej Unii Europejskiej. Unia Europejska, obejmująca 28 państw zamieszkiwanych przez ponad pół miliarda ludzi i będąca obok Stanów Zjednoczonych i Chin największą gospodarką świata, powinna w sposób oczywisty angażować się politycznie na arenie międzynarodowej. Jak zaznaczono w Przeglądzie ESDZ z 2013 r.: $W$ dzisiejszym świecie liczy się rozmiar i sita: UE jako catoś́ może osiagnać to, czego nie są w stanie osiagnać poszczególne państwa cztonkowskie $e^{31}$.

Po przeszło siedmiu latach od osiągnięcia przez ESDZ operacyjności można pokusić się o ocenę jej funkcjonowania. Nawiązując do pytań badawczych sformułowanych na wstępie, należy odpowiedzieć pozytywnie na pierwsze z nich, a zatem Unia potrzebuje dyplomacji, by móc skutecznie realizować swoje interesy w relacjach z państwami trzecimi i na forach organizacji międzynarodowych. W złożonym świecie relacji międzynarodowych najskuteczniejszym instrumentem promowania własnych interesów są dobre relacje z partnerami oraz dostęp do informacji, a to można osiągnąć za pomocą środków dyplomatycznych.

Czym cechuje się dyplomacja unijna i czy jest podobna do dyplomacji państw? Odpowiedź na to pytanie jest bardziej złożona. Jeśli traktować dyplomację jako sposób działania w celu realizacji swoich interesów, to w takim ujęciu różnic nie ma. Jeśli jednak nałożyć na to pewne instytucjonalne rozumienie dyplomacji, jako pewnych struktur, to różnice będą istotne. ESDZ nie jest, i nie ma ambicji, by być, ministerstwem spraw zagranicznych UE i nie taki też był cel jej ustanowienia. Ma pełnić funkcję koordynatora działań podejmowanych przez państwa członkowskie i instytucje Unii. Jednak jak zaznacza Günter Burghardt: spójność dziatań zewnętrznych Unii jest nieuchwytna idea, czesto przywotywana, rzadko jednak rozumiana $a^{32}$.

Ustanawiając ESDZ, starano się zachować równowagę między elementami międzyrządowymi i ponadnarodowymi. Ów pragmatyzm sprawil, że dyplomacja unijna wprawdzie zachowuje równowagę, jednak dzieje się to kosztem jej operacyjności i efektywności. Korekty w zakresie organizacji i działania ESDZ podjęte po 2013 r. wskazują na próbę wzmocnienia pozycji wysokiego przedstawiciela w kształtowaniu całości relacji zewnętrznych Unii, co może przynieść efekt w postaci większego angażowania w te działania ESDZ.

Z pewnością ustanowienie ESDZ przyczyniło się do wzrostu pozycji międzynarodowej Unii Europejskiej, jednak trudno ocenić, w jak dużym stopniu. Kiedyś Henry Kissinger pytał: Do kogo dzwonić w UE, gdy chce się porozmawiać na tematy polityki międzynarodowej?33 Traktat lizboński miał dać jednoznaczną odpowiedź na to pytanie.

31 European External Action Service, Przeglą..., s. 3.

32 G. Burghardt, Foreword, [w:] M. Gatti, European External Action Service..., s. XIV.

33 Sam Kissinger dystansuje się od autorstwa tego stwierdzenia, mówiąc, że padło ono w czasie jego rozmowy z ministrem spraw zagranicznych Irlandii i to zapewne ten polityk je wypowiedział, choć 
Jednak były sekretarz stanu USA stwierdza, że być może dzisiaj jest już jeden numer telefonu do Europy, ale nowe pytanie brzmi: Kto podniesie stuchawkę? ${ }^{34}$

\section{BIBLIOGRAFIA}

13. Deklaracja w sprawie wspólnej polityki zagranicznej i bezpieczeństwa. Wersje skonsolidowane Traktatu o Unii Europejskiej i Traktatu of funkcjonowaniu Unii Europejskiej, Dz.U. UE C, 2016, nr 202.

14. Deklaracja w sprawie wspólnej polityki zagranicznej i bezpieczeństwa. Wersje skonsolidowane Traktatu o Unii Europejskiej i Traktatu of funkcjonowaniu Unii Europejskiej, Dz.U. UE C, 2016, nr 202.

Blockmans S., Russack S., The Commissioners' Group on External Action - Key Political Facilitator, CEPS Special Report, no. 125, XII 2015, [online] http://aei.pitt.edu/70407/1/ SR125_SB_and_SR_Commissioners_Group_on_External_Action.pdf.

Burghardt G., Foreword, [w:] M. Gatti, European External Action Service. Promoting Coherence through Autonomy and Coordination, Leiden 2016.

Council of the European Union, Council conclusions on the EEAS Review. General Affairs Council meeting, Brussels, 17 XII 2013, [online] http://www.consilium.europa.eu/uedocs/cms_ data/docs/pressdata/EN/genaff/140141.pdf.

Decyzja Rady z dnia 26 lipca 2010 r. określająca organizację i zasady funkcjonowania Europejskiej Stużby Dziatań Zewnętrznych, Dz.U. UE L, 2010, nr 201.

European External Action Service, Annual Activity Report for 2016, 8 VI 2017, [online] https:// eeas.europa.eu/sites/eeas/files/aar2016_final_final.pdf.

European External Action Service, HQ Organisation Chart as of $16^{\text {th }}$ March 2018, [online] https://eeas.europa.eu/sites/eeas/files/2018-16-03_-_eeas_2.0_orgchart_0.pdf.

European External Action Service, Przeglad ESDZ 2013, [online] http://collections.internetmemory.org/haeu/20160313172652/http://eeas.europa.eu/library/publications/ 2013/3/2013_eeas_review_pl.pdf.

The European External Action Service and National Foreign Ministries. Convergence or Divergence?, red. R. Balfour, C. Carta, K. Raik, New York 2015.

The European External Action Service. European Diplomacy Post-Westphalia, red. D. Spence, J. Bátora, Basingstoke 2015.

Gatti M., European External Action Service. Promoting Coherence through Autonomy and Coordination, Leiden 2016.

Kuźniar R., Tożsamość międzynarodowa Europy (UE), [w:] Unia Europejska. Nowy typ wspólnoty międzynarodowej, red. E. Haliżak, S. Parzymies, Warszawa 2002.

zaznacza, że nie ma nic przeciwko przypisywaniu mu tego zdania. Transcript of the Kissinger-Sikorski Debate on Europe, by P. Cody, PISM, 27 VI 2012, s. 2, [online] http://www.pism.pl/files/?id_ plik=11024, 20 III 2018.

34 Tamże. 
Lefebvre M., Hillion C., The European External Action Service: Towards a Common Diplomacy?, Swedish Institute for European Policy Studies, European Policy Analysis, 2010:6, [online] http://www.asser.nl/upload/documents/712010_949533-SIEPS\%20-\%20EEAS\%20 -\%202010_6epa.pdf.

Lehne S., The Review of the European External Action Service in 2013, Carnegie Europe, 14 XI 2012, [online] http://carnegieeurope.eu/strategiceurope/50020.

McGann J.G., 2016 Global Go To Think Tank Index Report, University of Pennsylvania Scholary Commons, 26 I 2017, [online] https://repository.upenn.edu/cgi/viewcontent.cgi? article $=1011 \&$ context $=$ think_tanks.

Morgenstern-Pomorski J.-H., The Contested Diplomacy of the European External Action Service. Inception, Establishment and Consolidation, New York 2018.

Report of the High Representative of the Union for Foreign Affairs and Security Policy of 22 December 2015 to the Council on implementing the EEAS Review, Brussels, 11 I 2016 (OR. en), [online] http://data.consilium.europa.eu/doc/document/ST-5113-2016-INIT/en/pdf.

Smith K., European Union Foreign Policy in a Changing World, Cambridge 2003.

Szczerski K., Gtuchy telefon. O problemach Unii Europejskiej jako aktora polityki międzynarodowej, [w:] Amerykomania. Ksiega jubileuszowa prof. dr. hab. Andrzeja Mani, t. 2, red. W. Bernacki, A. Walaszek, Kraków 2012.

Transcript of the Kissinger-Sikorski Debate on Europe, by P. Cody, PISM, 27 VI 2012, [online] http://www.pism.pl/files/?id_plik=11024.

Węc J.J., Proces implementacji traktatu lizbońskiego w latach 2009-2013, „Politeja” 2015, nr 35, [online] http://dx.doi.org/10.12797/Politeja.12.2015.35.24.

Węc J.J., Traktat lizboński. Polityczne aspekty reformy ustrojowej Unii Europejskiej w latach 2007-2009, Kraków 2011.

Zięba R., Unia Europejska jako aktor stosunków międzynarodowych, Warszawa 2003.

Dr Agnieszka NITSZKE, doktor nauk humanistycznych w zakresie nauk o polityce. Adiunkt w Katedrze Studiów nad Procesami Integracyjnymi w Instytucie Nauk Politycznych i Stosunków Międzynarodowych UJ. Wiceprezes krakowskiego oddziału Polskiego Towarzystwa Studiów Europejskich, członek Polskiego Towarzystwa Studiów Międzynarodowych. Autorka m.in. monografii Zasady ustroju federalnego w państwach niemieckojezycznych. Studium porównawcze ustrojów federalnych Szwajcarii, Niemiec $i$ Austrii oraz artykułów poświęconych partiom politycznym w Europie i integracji europejskiej. 